\title{
Study of factors affecting maternal and fetal outcome in HIV positive women
}

\author{
Sumitra $\operatorname{Yadav}^{1}$, Ruchi Joshi ${ }^{2}$, Vishal Kale ${ }^{3}$ \\ ${ }^{1}$ Professor, ${ }^{2}$ Senior Registrar, Department of Obstetrics and Gynecology, Mahatma Gandhi Memorial Medical College \\ Indore, Madhya Pradesh, India \\ ${ }^{3}$ Department of Pediatrics, Mahatma Gandhi Memorial Medical College Indore, Madhya Pradesh, India
}

Received: 11 November 2016

Revised: 06 December 2016

Accepted: 07 December 2016

\author{
*Correspondence: \\ Dr. Ruchi Joshi, \\ E-mail: sensibleruchi@gmail.com
}

Copyright: ( ) the author(s), publisher and licensee Medip Academy. This is an open-access article distributed under the terms of the Creative Commons Attribution Non-Commercial License, which permits unrestricted non-commercial use, distribution, and reproduction in any medium, provided the original work is properly cited.

\begin{abstract}
Background: HIV virus infection was detected first time in India in Tamil Nadu in April 1986; India has the third largest HIV epidemic in the world. In 2013, HIV prevalence in India was an estimated 0.3 percent. The pregnant women and her unborn child who are HIV reactive are mostly innocent bearers of the brunt of the infection. Motherto-child transmission of HIV is a major route of new infections in children. Without any intervention, the risk of transmission of HIV from infected pregnant women to her child is estimated to be around 20- 45\%.Early diagnosis of children born to HIV positive mother using HIV DNA PCR and treating children who are diagnosed HIV-positive with antiretroviral drugs within their first 12 weeks of life reduces mortality by $75 \%$.

Methods: This retrospective data analytic study of HIV positive pregnant women who attended antenatal clinic and delivered at M.Y. Hospital, Indore from January 2011 to December 2013 .For screening of ANC patients ELISA method was used. For the children, HIV DNA was done by sending the dried blood smear on blot paper and was sent to the reference laboratory Kasturba Hospital, Mumbai and used for diagnosis at 6 week and 6 month.

Results: Only $50 \%$ of HIV positive children were started on ART, $20 \%$ died, $20 \%$ loss to follow up and $10 \%$ were not willing for follow up. Also $30 \%$ mothers practiced mixed feeding. Neonatal mortality rate was 54.87 per thousand live births which is more than the seronegative mothers.

Conclusions: First HIV DNA testing can be done at 72 hours to detect antenatal HIV transmission. Early testing can pick up these cases early and ensure treatment. Mixed feeding should be strongly discouraged by counseling and modern methods of communication.
\end{abstract}

Keywords: ART, HIV, Pregnancy

\section{INTRODUCTION}

Acquired immunodeficiency syndrome (AIDS) was first described in 1981, and it is currently one of the worst global pandemics in recorded HIV virus infection was detected first time in India in Tamil Nadu in April 1986, India has the third largest HIV epidemic in the world. In 2013, HIV prevalence in India was an estimated 0.3 percent. The pregnant women and her unborn child who are HIV reactive are mostly innocent bearers of the brunt of the infection. Mother-to-child transmission of HIV is a major route of new infections in children. HIV prevalence among adult population in India has declined consistently over last one decade from $0.4 \%$ in the year 2000 to $0.27 \%$ in 2011 . This decline reflects impact of scaled up HIV prevention interventions under the National AIDS Control Programme (NACP).On the contrary reduction in new HIV infections among children 
is only about $35 \%$.Without any intervention the risk of transmission is between 20 to $45 \%$.

NACP has launched Prevention of Parent to Child Transmission (PPTCT) of HIV service in the year 2002, to address burden of HIV among children. This includes HIV testing service to all pregnant women enrolled into antenatal care along with provision of ARV prophylaxis. The introduction of highly active antiretroviral therapy (HAART), choice of delivery based on viral load and infant feeding counselling have changed the fate of the child of HIV Positive mother especially in developed countries where vertical transmission has virtually been eliminated. $^{2} 20 \%$ transmissions occur before 36 weeks gestation, $50 \%$ in the days before delivery and $30 \%$ intrapartum. ${ }^{3}$ Transmission rates for breast feeding may be as high as $30-40 \%$ and are associated with systemic HIV burden. ${ }^{4}$ The viral load should not be used to determine whether to initiate antiretroviral therapy in pregnancy. ${ }^{6}$ Getting to Zero 2011-2015 UNAIDS strategy has many goals and vision, amongst these one of the vision is to get to Zero New infection. One of these goals for 2015 is sexual transmission of HIV reduction by half, vertical transmission of HIV elimination and AIDS related maternal mortality reduction by half. ${ }^{7}$

The NACO Technical Estimate Report (2015) estimated that out of 29 million annual pregnancies in India, 35,255 occur in HIV positive pregnant women. In the absence of any intervention, an estimated (2015) cohort of 10,361 infected babies will be born annually. The PPTCT programme aims to prevent the perinatal transmission of HIV from an HIV infected pregnant mother to her newborn baby. The programme entails counselling and testing of pregnant women in the ICTCs.

With effect from 1st January 2014, pregnant women who are found to be HIV positive are initiated on lifelong ART irrespective of CD4 count and WHO clinical Staging; their new-born (HIV exposed) babies are initiated on 6 weeks of Syrup Nevirapine immediately after birth so as to prevent transmission of HIV from mother to child and is extended to 12 weeks of Syrup Nevirapine if the duration of the ART of mother is less than 24 weeks.

The HIV exposed baby is initiated on Cotrimoxazole prophylaxis at 6 weeks and is tested for HIV DNA PCR at 6 weeks by DBS (Dry Blood Spot) collection. If the DBS sample is positive for HIV DNA PCR, then a repeat DBS sample is tested for HIV DNA PCR. The HIV exposed baby is then initiated on lifelong ART at the earliest if confirmed HIV positive through 2 DNA PCR test.

The findings from this study are thus expected to reflect the actual effect of HIV infection. Early diagnosis of children born to HIV positive mother using HIV DNA PCR and treating children who are diagnosed HIVpositive with antiretroviral drugs within their first 12 weeks of life reduces mortality by $75 \%$. Besides medical care, the main factors detrimental in future outcome of children born to HIV positive mothers are the socioeconomic status and the educational status of the parents.

\section{METHODS}

This Retrospective data analytic study of HIV positive pregnant women who attended antenatal clinic and delivered at M.Y. Hospital, Indore from January 2011 to December 2013. For this study, analysis of the mothers with HIV positive serology up to their delivery and follow up of their babies up to 18 month period was done. The analysis was done on the basis of data collected from PPTCT center in department of Obstetrics and Gynaecology, labour room records, nursery records and ART center. For screening of ANC patients ELISA method was used. The kit used detects antibodies to HIV1 and HIV-2.The test is repeated and the algorithm for diagnosis is followed. For the children, HIV DNA was used for diagnosis at 6 week and 6 month follow up. The HIV DNA test was done by sending the dried blood smear on the blot paper, it was sent to the reference laboratory Kasturba Hospital, Mumbai. In case of positive result the whole blood sample was sent for confirmation. Antenatal history, socioeconomic status, CD4 count and comorbidities were studied from the records in PPTCT centre at MYH, Indore.

\section{RESULTS}

Table 1: OPD Analysis during the study period.

\begin{tabular}{|l|l|}
\hline Category & No. of patients \\
\hline Total ANC patients & 42585 \\
\hline HIV Positive mothers & 173 \\
\hline $\begin{array}{l}\text { Total babies delivered to HIV } \\
\text { positive mothers }\end{array}$ & 164 \\
\hline $\begin{array}{l}\text { Total babies tested positive during } \\
\text { the study period }\end{array}$ & 10 \\
\hline Babies tested positive at 6 weeks & 7 \\
\hline Babies tested positive at 6 months & 1 \\
\hline Babies tested positive at 18 months & 2 \\
\hline
\end{tabular}

Table 2: CD4 count in mothers in HIV positive and non-positive babies.

\begin{tabular}{|lll|}
\hline CD4 & $\begin{array}{l}\text { No. of mothers } \\
\text { with HIV } \\
\text { positive babies }\end{array}$ & $\begin{array}{l}\text { No. of mothers } \\
\text { with Non-HIV } \\
\text { positive babies }\end{array}$ \\
\hline$>1000$ & $110 \%$ & $75.55 \%$ \\
\hline $500-1000$ & $220 \%$ & $5946.44 \%$ \\
\hline $250-500$ & $770 \%$ & $4031.49 \%$ \\
\hline$<250$ & 0 & $2015.74 \%$ \\
\hline
\end{tabular}

Chi-Square $=6.43 ;$ Degrees of Freedom $=2 ;$ Probability $=$ 0.040 
Table 3: Agewise distributions of mothers in HIV positive and non-positive babies.

\begin{tabular}{|lllll|}
\hline Age & \multicolumn{2}{l}{$\begin{array}{l}\text { No. of mothers } \\
\text { with HIV positive } \\
\text { babies }\end{array}$} & \multicolumn{2}{l|}{$\begin{array}{l}\text { No. of mothers } \\
\text { with non-HIV } \\
\text { positive babies }\end{array}$} \\
\hline$<20$ & 1 & $10 \%$ & 13 & $8.60 \%$ \\
\hline $20-25$ & 6 & $60 \%$ & 86 & $56.94 \%$ \\
\hline $26-30$ & 3 & $3 \%$ & 41 & $27.15 \%$ \\
\hline$>31$ & 0 & & 11 & $7.28 \%$ \\
\hline
\end{tabular}

Chi-Square $=0.792 ;$ Degrees of Freedom $=3$; Probability $=$ 0.851

Table 4: Parity of mothers in HIV positive and nonpositive babies.

\begin{tabular}{|lllll|}
\hline Parity & \multicolumn{2}{l}{$\begin{array}{l}\text { No. of mothers } \\
\text { with HIV positive } \\
\text { babies }\end{array}$} & \multicolumn{2}{l|}{$\begin{array}{l}\text { No. of mothers } \\
\text { with non-HIV } \\
\text { positive babies }\end{array}$} \\
\hline G1 & 1 & $10 \%$ & 40 & $26.94 \%$ \\
\hline G2 & 7 & $70 \%$ & 66 & $43.70 \%$ \\
\hline G3 & 1 & $10 \%$ & 34 & $22.51 \%$ \\
\hline G4 & 1 & $10 \%$ & 6 & $3.97 \%$ \\
\hline G5 & 0 & & 2 & $1.32 \%$ \\
\hline G6 & 0 & & 1 & $0.665 \%$ \\
\hline
\end{tabular}

Chi-Square $=4.04 ;$ Degrees of Freedom $=5$; Probability $=$ 0.544

Table 5: Education status of mothers in HIV positive and non-positive babies.

\begin{tabular}{|c|c|c|c|c|}
\hline Education & \multicolumn{2}{|c|}{$\begin{array}{l}\text { No. of mothers } \\
\text { with HIV positive } \\
\text { babies }\end{array}$} & \multicolumn{2}{|c|}{$\begin{array}{l}\text { No. of mothers } \\
\text { with non-HIV } \\
\text { positive babies }\end{array}$} \\
\hline Illiterate & 4 & $40 \%$ & 66 & $43.70 \%$ \\
\hline Secondary & 4 & $40 \%$ & 73 & $48.34 \%$ \\
\hline $\begin{array}{l}12 \text { th plus } \\
\text { and } \\
\text { graduate }\end{array}$ & 2 & $20 \%$ & 12 & $7.94 \%$ \\
\hline
\end{tabular}

Table 6: Period of gestation in mothers in HIV positive and non-positive babies.

\begin{tabular}{|lllll|}
\hline $\begin{array}{l}\text { Period of } \\
\text { gestation }\end{array}$ & $\begin{array}{l}\text { No. of mothers } \\
\text { with HIV positive } \\
\text { babies }\end{array}$ & \multicolumn{2}{l|}{$\begin{array}{l}\text { No. of mothers } \\
\text { with non-HIV } \\
\text { positive baloies }\end{array}$} \\
\hline$<37$ weeks & 3 & $30 \%$ & 90 & $59.60 \%$ \\
\hline $\begin{array}{l}37-40 \\
\text { weeks }\end{array}$ & 7 & $70 \%$ & 57 & $37.74 \%$ \\
\hline$>40$ weeks & 0 & & 4 & $2.64 \%$ \\
\hline
\end{tabular}

Chi-Square $=4.14 ;$ Degrees of Freedom $=2$; Probability $=$ 0.126

The study which was conducted for a period of 3 years from Jan 2011 to Dec 2013 at MGMMC and M.Y hospital where 173 pregnant women out of 42585 attending antenatal clinic were tested positive. 164 delivered at our institute. Cesarean section had a lower rate of transmission than normal delivery. On following up 10 babies tested positive. Perinatal, Neonatal and Infant mortality rates of seropositive mothers were more than double of the seronegative mothers thus affecting the state and nation's mortality rates. Awareness about the disease will help in early detection and henceforth early treatment which will improve the outcome. Also despite counselling about the ill hazards of mixed feeding, 30\% of the affected babies were mixed fed which might have caused the transmission.

Table 7: Mode of delivery in mothers HIV positive and non-positive babies.

\begin{tabular}{|lllll|}
\hline $\begin{array}{l}\text { Mode of } \\
\text { delivery }\end{array}$ & \multicolumn{2}{l}{$\begin{array}{l}\text { No. of mothers } \\
\text { with HIV positive } \\
\text { babies }\end{array}$} & \multicolumn{2}{|l|}{$\begin{array}{l}\text { No. of mothers } \\
\text { with non-HIV } \\
\text { positive babies }\end{array}$} \\
\hline Total LSCS & 4 & $40 \%$ & 54 & $35.76 \%$ \\
\hline $\begin{array}{l}\text { Normal } \\
\text { labour }\end{array}$ & 6 & $60 \%$ & 97 & $64.23 \%$ \\
\hline $\begin{array}{l}\text { Chi-Square }=0.731 \text {; Degrees } \\
0.787\end{array}$ & & & \\
\hline
\end{tabular}

Table 8: Need for nursery admission in HIV positive and non-positive babies.

\begin{tabular}{|c|c|c|}
\hline $\begin{array}{l}\text { Mode of } \\
\text { delivery }\end{array}$ & $\begin{array}{l}\text { No. of mothers } \\
\text { with HIV positive } \\
\text { babies }\end{array}$ & $\begin{array}{l}\text { No. of mothers } \\
\text { with non-HIV } \\
\text { positive babies }\end{array}$ \\
\hline Total LSCS & $4 \quad 40 \%$ & $54 \quad 35.76 \%$ \\
\hline $\begin{array}{l}\text { Normal } \\
\text { labour }\end{array}$ & $60 \%$ & $64.23 \%$ \\
\hline
\end{tabular}

Table 9: Need for nursery admission in HIV positive and non-positive babies.

\begin{tabular}{|lllll|}
\hline Outcome & \multicolumn{2}{l|}{$\begin{array}{l}\text { No. of mothers } \\
\text { with HIV positive } \\
\text { babies }\end{array}$} & \multicolumn{2}{l|}{$\begin{array}{l}\text { No. of mothers } \\
\text { with non-HIV } \\
\text { positive babies }\end{array}$} \\
\hline Healthy & 6 & $60 \%$ & 112 & $72.72 \%$ \\
\hline Nursery & 4 & $40 \%$ & 27 & $27.27 \%$ \\
\hline
\end{tabular}

Chi-Square $=0.754 ;$ Degrees of Freedom $=1$; Probability $=$ 0.385

Table 10: Causes of death in neonatal period.

\begin{tabular}{|ll|}
\hline Cause of death & No of babies \\
\hline Prematurity/HMD & 4 \\
\hline Septicemia & 3 \\
\hline HIE Grade3 & 1 \\
\hline
\end{tabular}

\section{DISCUSSION}

Maternal HIV transmission is the primary means by which infants become infected. Hence prevention of maternal HIV transmission is of paramount importance. 
Table 11: Comparison of mortality rates with normal ANC patients at MY.

\begin{tabular}{|c|c|c|c|}
\hline Group & $\begin{array}{l}\text { Children } \\
\text { born to } \\
\text { HIV } \\
\text { positive } \\
\text { mothers }\end{array}$ & $\begin{array}{l}\text { Children } \\
\text { born to } \\
\text { seronegative } \\
\text { mothers }\end{array}$ & $\begin{array}{l}\mathbf{P} \\
\text { value }\end{array}$ \\
\hline $\begin{array}{l}\text { Perinatal mortality } \\
\text { rate }\end{array}$ & $\begin{array}{l}48.78 \text { per } \\
1000 \text { live } \\
\text { births }\end{array}$ & $\begin{array}{l}25 \text { per } 1000 \\
\text { live births }\end{array}$ & 0.008 \\
\hline $\begin{array}{l}\text { Neonatal mortality } \\
\text { rate }\end{array}$ & $\begin{array}{l}54.87 \text { per } \\
1000 \text { live } \\
\text { births }\end{array}$ & $\begin{array}{l}28 \text { per } 1000 \\
\text { live births }\end{array}$ & 0.005 \\
\hline $\begin{array}{l}\text { Infant mortality } \\
\text { rate }\end{array}$ & $\begin{array}{l}109.76 \\
\text { per } 1000 \\
\text { live }\end{array}$ & $\begin{array}{l}62 \text { per } 1000 \\
\text { live births }\end{array}$ & 0.001 \\
\hline
\end{tabular}

Table 12: Outcome of children diagnosed HIV positive during study period $(n=10)$.

\begin{tabular}{|c|c|c|c|}
\hline Outcome & $\begin{array}{l}\text { No. of } \\
\text { children }\end{array}$ & $\begin{array}{l}\% \text { of } \\
\text { children }\end{array}$ & Outcome \\
\hline $\begin{array}{l}\text { HIV positive } \\
\text { children on ART }\end{array}$ & 5 & $50 \%$ & $\begin{array}{l}\text { HIV } \\
\text { Positive } \\
\text { children } \\
\text { on ART }\end{array}$ \\
\hline $\begin{array}{l}\text { HIV positive } \\
\text { children LFU }\end{array}$ & 2 & $20 \%$ & $\begin{array}{l}\text { HIV } \\
\text { Positive } \\
\text { children } \\
\text { LFU }\end{array}$ \\
\hline $\begin{array}{l}\text { HIV positive } \\
\text { children died }\end{array}$ & 2 & $20 \%$ & $\begin{array}{l}\text { HIV } \\
\text { Positive } \\
\text { children } \\
\text { died }\end{array}$ \\
\hline $\begin{array}{l}\text { HIV positive } \\
\text { children's parents } \\
\text { not willing for } \\
\text { treatment }\end{array}$ & 1 & $10 \%$ & $\begin{array}{l}\text { HIV } \\
\text { Positive } \\
\text { children's } \\
\text { parents } \\
\text { not } \\
\text { willing } \\
\text { for } \\
\text { treatment }\end{array}$ \\
\hline $\begin{array}{l}\text { Growth failure in } \\
\text { children with HIV }\end{array}$ & 4 & $40 \%$ & $\begin{array}{l}\text { Growth } \\
\text { failure in } \\
\text { children } \\
\text { with HIV }\end{array}$ \\
\hline $\begin{array}{l}\text { HIV positive } \\
\text { children's who } \\
\text { were breast feed }\end{array}$ & 5 & $50 \%$ & $\begin{array}{l}\text { HIV } \\
\text { Positive } \\
\text { children's } \\
\text { who were } \\
\text { breast } \\
\text { feed }\end{array}$ \\
\hline $\begin{array}{l}\text { HIV positive } \\
\text { children's who } \\
\text { were mixed feed }\end{array}$ & 3 & $30 \%$ & $\begin{array}{l}\text { HIV } \\
\text { Positive } \\
\text { children's } \\
\text { who were } \\
\text { mixed } \\
\text { feed }\end{array}$ \\
\hline
\end{tabular}

The study was conducted on all babies delivered to HIV positive pregnant women who were attending antenatal clinic or delivering in Department of Obstetrics and Gynecology at MYH Indore. The study period was three years. In the present study 173 cases of HIV positive pregnant women were registered for follow-up of maternal and perinatal outcome. As is common knowledge the route of HIV infection in sexual transmission heterosexual contact has emerged as the single largest cause for spread of HIV in South East Asia.

The fetus becomes the innocent bearer of the disease. These children were called for follow up at 6 wks ,6 months and 18 months .Out of the total 173 ANC Patients Registered with PMTCT center, 161mother gave birth to 164 babies (including 1 triplets and 1 twin ). 12 mothers were excluded as they had an abortion or an ectopic pregnancy or were lost to follow up. The Perinatal mortality rate was 48.78 per thousand live births and still births, and neonatal mortality rate was 50.63 per thousand live births. Both were significantly higher than the mortality rate in seronegative mothers.

Kennedy D et al studied outcome of children in HIV positive mothers in South Africa. ${ }^{8}$ The stillbirth rate in the HIV-positive population was 17.1/1 000 births, compared with 8.3/1 000 in the HIV-negative population. The early neonatal death rate in the HIV-positive population was 4.6/1 000 live births, compared with 3.1/1 000 in the HIV-negative population. The perinatal mortality rate in the HIV-positive population was 21.7/1000 births, compared with 11.7 in the HIVnegative population.

Age: In the present study $>60 \%$ were belonging to age group <25 yrs. But age of the mother did not affect the HIV transmission rates. Patel et al. (1998) reported maximum HIV seropositivity in 20-25 years age group $(51,44 \%)$, followed by $15-19$ years $(28,24.1 \%)$ minimum seropositivity was observed after 35 years (1, $0.8 \%)$. Kaizad et al reported that amongst $683(1.03 \%)$ HIV positive pregnancies, $42(6.14 \%)$ were adolescents. ${ }^{9}$

Education: In present study only $10 \%$ woman passed.

Occupation: In present study most of the antenatal women were housewife $40(70 \%)$ and their Husband was unskilled workers 93 (56.70\%), Drivers 26 (15.85\%) and on Touring Service $16(9.75 \%)$. The occupation of father did not affect the mother to child transmission. In this study by Gopalan et al similar results were observed $89.3 \%$ women were housewives. Amongst the occupation of their husbands, it was observed that none were unemployed. The largest group comprised of labourers. Ravi Kumaran et al also found that $7.5 \%$ (3) of HIV positive antenatal women were housewives and $25 \%$ were unskilled workers. The low socioeconomic status and lack of education were main reason for the lack of awareness of the infection and also for loss of follow ups. 
Treatment received: In the present study only 55 $(34.16 \%)$ HIV positive pregnant women were eligible for treatment as they had low CD4 counts. The treatment was started but was not effective in preventing HIV transmission as $60 \%$ were HIV positive against $30 \%$ babies where mothers did not receive any treatment. The main reason for ineffectiveness of treatment in preventing HIV transmission was delayed commencement of treatment. The difference was stastically significant with $P$ value 0.032 .

CD4 count: The CD4 counts were less than 500 in $70 \%$ (7 out of 10) mothers with HIV positive babies. The CD4 counts were less than 500 in $47.2 \%$ (60 out of 151) mothers with HIV negative babies .The difference was significant stastically as $\mathrm{P}$ value 0.040 .

Mode of delivery: LSCS was done only for obstetrics indication as per the current guidelines. The rate of transmission was marginally less than normal labour.

Period of gestation: In present study, the incidence of (<37 wks) preterm deliveries was maximum52\%.The maximum transmission of HIV occurs in third trimester ,the rate of transmission of HIV was more in the term babies $(70 \%)$ as compared to preterm babies $(30 \%)$.

Feeding: Breast-feeding is an important mode of transmission of HIV infection in developing countries. The risk of HIV infection via breast-feeding is highest in the early months of breast-feeding. ${ }^{12}$ Exclusive breastfeeding has been reported to carry a lower risk of HIV transmission than mixed feeding. Mothers known to be HIV-infected should only give commercial infant formula milk as a replacement feed when specific conditions are met (referred to as AFASS - affordable, feasible, acceptable, sustainable and safe in the 2006 WHO recommendations on HIV and Infant Feeding. Although exclusive breast feeding was advised as per the recent recommendations, mothers in both groups practiced top feeding and mixed feeding .Faulty feeding practices were responsible for transmission in $30 \%$ babies in our study. But as faulty practices were seen in both the groups the difference was not statically significant.

Neonatal outcome: The birth weight of the babies was below $2.5 \mathrm{kgs}$ in $40 \%$ HIV positive babies and $47.67 \%$ of the Non HIV positive babies. Preterm/Low birth weight was most common indication for admission in both the groups, followed by septicemia, NNHB and birth asphyxia. The most common cause of deaths in our set up was prematurity followed by septicemia.

In a retrospective study of $9504 \mathrm{HIV}$-infected pregnant women in Botswana, the overall rates of adverse pregnancy outcomes were as follows: 5 percent had stillbirth, $24 \%$ had preterm delivery (prior to 37 weeks), and $19 \%$ had a small for gestational age (SGA) infant. ${ }^{11}$
There were 6 stillbirths and 8 neonatal deaths in the study. The mortality was highest in preterm low birth weight babies. Higher the incidence of IUGR so the cause of perinatal mortality which took highest toll was low birth weight and associated complications.

Out of the $10 \mathrm{HIV}$ positive babies, 5 babies were started on ART irrespective of their CD4 counts, they are all healthy and 2 have some growth failure (grade 2). Two babies were lost to follow up. 2 died before ART was started and 1 child's parents refused treatment as the mother was terminally ill and father has abandoned them.

In a study conducted at Manipur, symptomatic (CDC III/IV) HIV-1 infection is associated with a significantly increased rate of miscarriage, low birth weight, intrauterine fetal death and preterm delivery. Perinatal, infant and maternal deaths were limited to symptomatic women. $^{14}$

\section{CONCLUSION}

HIV has emerged as a major pandemic all over and it is challenging day by day to improve treatments and prevention modalities. Of the total 42585 women attending antenatal OPD at M.Y. Hospital, nearly all the mothers were tested at other primary care hospitals and MYH if the patients were untested. Counseling regarding HIV and STDs should be available right from adolescence at school level. Media plays a great role in it. Parents and siblings should also give proper guidance. As 14 babies were expired in neonatal period, without HIV testing. The first HIV DNA testing can be done at 72 hours to detect antenatal HIV transmission. Early testing can pick up these cases early and ensure treatment. Antenatal women who are HIV positive face numerous risks-social stigmas, morbidity associated with the disease, debilitated state and the significant risk of vertical transmission. HIV screening of antenatal women is mandatory for the successful prevention and management of AIDS. All pregnant women should receive HIV education and counseling and be offered voluntary HIV testing as part of their regular antenatal care. Under voluntary testing guidelines, all pregnant women should be able to learn their HIV status. This will enable the women to take informed decision regarding termination of pregnancy or continuation of pregnancy and proper interventions to prevent perinatal transmission can be taken. Husband and family members of these women should be proper counseled properly so as to provide a good quality of life for the women. Regular treatment and follow-up of the patients ensure almost normal life spans for them. A women being the most socially deprived in our community, thus requires firm support from the husband and family members. A significant number of patients were lost to follow up or were certified without testing, this can be prevented by proper counseling and education of parents, village level workers like ASHA, can be trained to prevent loss to follow up of rural patients. 
Funding: No funding sources

Conflict of interest: None declared

Ethical approval: The study was approved by the Institutional Ethics Committee

\section{REFERENCES}

1. Centers for Disease Control and Prevention: AIDS Surveillance Trends, Slide Set. 2011.

2. Operative Guidelines for Lifelong ART for All Pregnant Women Living With HIV for Prevention of Parent to Child Transmission (PPTCT) of HIV in India, NACO, December 2013.

3. Koutis AP, Bultreys M, Nesheim SR. Understanding the Timing of HIV Transmission from Mother to Infant. JAMA. 2001;285:709.

4. Kourtis AP, Jamieson DJ, de Vincenzi I. Prevention of Human Immunodeficiency Virus 1 Transmission to the Infant through Breastfeeding: New Development. Am J Obstet Gynecol. 2007;197:S113.

5. Cotter AM, Brookfield KF, Duthely LM. Duration Of Membrane Rupture And Risk Of Perinatal Transmission Of HIV 1 In The Era Of Combination Antiretroviral Therapy. Am J Obstet Gynecol. 2012;207:482.

6. Panel on Treatment of HIV Infected Pregnant Women And Prevention Of Perinatal Transmission. Recommendation For Use of Antiretroviral Drugs In Pregnant HIV 1 Infected Woman For Maternal Health And Interventions To Reduce Perinatal HIV Transmission In United State. 2012.

7. Getting to Zero, UNAIDS 2011-2015 Strategy, Joint United Nations Programme On HIV/AIDS (UNAIDS)/10.12E / JC2034E. 2010.
8. Kennedy D. The effect of maternal HIV status on perinatal outcome at Mowbray Maternity Hospital and referring midwife obstetric units, Cape Town. SAJOG. 2012;18(1).

9. Pradhan BK, Sundar R. Socioeconomic impact of HIV and AIDS in India. United Nations Development Programme, 2006.

10. Ahir SP, Chavan V, Kerkar S. Antiretroviral treatment, viral load of mothers and perinatal HIV transmission in Mumbai, India. The Indian Journal of Medical Research. 2013;138(2):201-8.

11. Ahmed S, Kim MH, Abrams EJ. Risks and benefits of lifelong antiretroviral treatment for pregnant and breastfeeding women: a review of the evidence for the Option $\mathrm{B}+$ approach. Curr Opin HIV AIDS. 2013;8:474-89.

12. Saharan S, Lodha R, Agarwal R. Perinatal HIV, AIIMS NICU Protocol, 2010.

13. HHS Panel on Treatment of HIV-Infected Pregnant Women and Prevention of Perinatal Transmission. Recommendations for Use of Antiretroviral Drugs in Pregnant HIV-1-Infected Women for Maternal Health and Interventions to Reduce Perinatal HIV Transmission in the United States. Rockville, MD: Department of Health and Human Services; 2012.

14. Kumar RM, Uduman SA, Khurranna AK. Impact of maternal HIV-1 infection on perinatal outcome. International Journal of Gynecology and Obstetrics. 1995;49(2):137-43.

Cite this article as: Yadav S, Joshi R, Kale V. Study of factors affecting maternal and fetal outcome in HIV positive women. Int J Reprod Contracept Obstet Gynecol 2017;6:256-61. 